\title{
THE GROWTH PERFORMANCE AND COSTS OF REARING FRIESIAN CROSSBREED DAIRY YOUNG STOCK IN MALAYSIAN COMMERCIAL FARM
}

\section{Ang Xin Tong*), Norhariani Mohd Nor*)1, Shanmugavelu Sithambaram*), Mark Hiew Wen Han*), Uswah Khairuddin $^{* *)}$, Mohd Ibrahim Shapiai**), Nurul Aisyah Mohd Suhaimi ${ }^{* * *}$, Peter Lee Ah Kong $^{* * * *)}$, Muhammad Ali Hanapiah ${ }^{* * * * *)}$}

\author{
*) Faculty of Veterinary Medicine, Universiti Putra Malaysia \\ 43400 UPM Serdang, Selangor, Malaysia \\ ${ }^{* *}$ Universiti Teknologi Malaysia \\ Jl. Semarak, 54100 Kuala Lumpur, Malaysia \\ ${ }^{* * *}$ Universiti Sultan Zainal Abidin \\ Besut Campus, 22200 Besut, Terengganu, Malaysia \\ ${ }^{* * * *}$ Department of Veterinary Services Sabah (DVS) \\ Wisma Pertanian Sabah, 88999 Kota Kinabalu, Sabah, Malaysia \\ ${ }^{* * * * * *}$ Pusat Ternakan Haiwan Air Hitam \\ Jl. Batu Pahat, 86009 Kluang, Johor, Malaysia
}

\begin{abstract}
The important elements in rearing dairy young stock are good farm management, proper growth and optimal costs of rearing. A survey on these important elements was conducted at two commercial farms in Johor and Sabah in 2019. The farm herd size is 214 heads and 2,221 heads with 163,682 litres and 4.2 mil. litres of milk production, in Johor and Sabah respectively. In addition, the body weight data of 188 dairy young stock was collected and analysed to determine the growth performance using polynomial growth function. The results showed the two farms have youngstock with different Friesian blood levels $(60 \%$ and $70 \%$ in Johor, and $87.5 \%$ in Sabah) with different growth performance. The average weight of dairy young stock with $60 \%, 70 \%$ and $87.5 \%$ Friesian blood levels at birth were $21.31 \pm 3.70 \mathrm{~kg}, 22.33 \pm 2.23 \mathrm{~kg}$ and $26.55 \pm 2.68 \mathrm{~kg}$, respectively, while average weight at 3 months of age were $45.00 \pm 7.07 \mathrm{~kg}, 55.57 \pm 8.36 \mathrm{~kg}$ and $75.84 \pm 12.54 \mathrm{~kg}$, respectively. Heifers with $87.5 \%$ Friesian blood levels was bred at 15 months of age $(444 \mathrm{~kg})$ while heifers with lower Friesian blood levels was bred 6 months later $(250 \mathrm{~kg})$. The average rearing (feed) cost was RM4,932 (USD1,194)/heifer. The findings of this study can give awareness and insights in the performance and costs of rearing crossbreed dairy young stock in tropics.
\end{abstract}

Keywords: tropical, dairy, young stock, management, rearing cost

\begin{abstract}
Abstrak: Unsur-unsur penting dalam pemeliharaan ternak muda perah adalah manajemen peternakan yang baik, pertumbuhan yang tepat dan biaya pemeliharaan yang optimal. Sebuah survei tentang elemen-elemen penting ini dilakukan di dua peternakan komersial di Johor dan Sabah pada tahun 2019. Ukuran kawanan peternakan adalah 214 ekor dan 2.221 ekor dengan 163.682 liter dan 4,2 juta ekor. liter produksi susu, masing-masing di Johor dan Sabah. Selain itu, data bobot badan 188 ekor sapi muda perah dikumpulkan dan dianalisis untuk mengetahui performa pertumbuhan menggunakan fungsi pertumbuhan polinomial. Hasil penelitian menunjukkan kedua peternakan memiliki bibit muda dengan kadar darah Friesian yang berbeda (60\% dan 70\% di Johor, dan 87,5\% di Sabah) dengan performa pertumbuhan yang berbeda. Rata-rata berat badan anak sapi perah dengan kadar darah Friesian $60 \%, 70 \%$ dan 87,5\% saat lahir adalah masing-masing 21,31 $33,70 \mathrm{~kg}$,

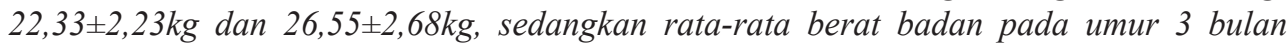
adalah $45,00 \pm 7.07 \mathrm{~kg}, 55.57 \pm 8.36 \mathrm{~kg}$, dan $75.84 \pm 12.54 \mathrm{~kg}$, masing-masing. Sapi dara dengan kadar darah Friesian 87,5\% dikawinkan pada usia 15 bulan (444kg) sedangkan sapi dara dengan kadar darah Friesian lebih rendah dikawinkan 6 bulan kemudian (250kg). Biaya pemeliharaan (pakan) rata-rata adalah RM4.932 (USD1.194)/heifer. Temuan penelitian ini dapat memberikan kesadaran dan wawasan tentang kinerja dan biaya pemeliharaan ternak muda perah persilangan di daerah tropis.
\end{abstract}

Kata kunci: tropis, susu, ternak muda, manajemen, biaya pemeliharaan

\footnotetext{
${ }^{1}$ Corresponding author:

Email: norhariani@upm.edu.my
} 


\section{INTRODUCTION}

The livestock sector plays a vital role in fulfilling the demand for milk, meat, and dairy products. The livestock subsector in Malaysia contributed 14.9\% of agro-food production in 2019 (Uzir, 2019). The Malaysian government had developed National Agro-food Policy 2011-2020 and Dairy Plan 20212025 to improve the dairy industry. Besides, banks (e.g., Agrobank and commercial banks) and financial organizations (e.g., Perbadanan Usahawan Nasional Berhad) also provide loan schemes for the livestock and dairy industry in Malaysia (Faghiri et al. 2019). Consequently, through an efficient livestock system approach, increasing production capacity, and maintaining optimal production costs, a $100 \%$ selfsufficiency level (SSL) in 5 years can be achieved. It showed that in 2019, there was a 37\% gap for Malaysia before it could become self-sufficient in fresh milk production. As per capita consumption of milk showed an increasing trend from 1.5 liters to 2 liters (20142019) (DVS, 2020), the Malaysian dairy industry needs all efforts to improve the farm production or else, in the future, it could remain to be relying heavily on milk importation to fulfill the domestic demand.

A dairy farm needs on average $25 \%$ of healthy and genetically superior dairy young stock annually to replace the culled dairy cows and maintain the herd size (De Vries, 2017). As genetic selection enable the sustainability of the heifer production system (Davis \& White, 2020), the Department of Veterinary Services (DVS), Malaysia, started a crossbreeding program between the Sahiwal and the Friesian breed to produce high milk producer Mafriwal crossbreed with local disease resistance (Mastura et al. 2019). Monitoring the growth of young stock at specific times during its development enables the dairy farmer to be sure their young dairy stocks are on target, ensuring good performance in future dairy cows and increasing farm profits (Costa et al. 2021). For example, the calf's birth weight is one of the important factors to the subsequent growth, development (Van Eetvelde \& Opsomer, 2017), and consequently on milk production (Rahbar et al. 2016). Yet, it is not a common practice for smallscale and semi-holder dairy farms to weigh their young stock as an electronic weighing scale is costly to obtain (Lukuyu et al. 2016; Tebug et al. 2018). Understanding the growth of the young dairy stock can enhance the feeding strategy and management appropriately to optimize heifer production (Franco et al. 2017).
Rearing a heifer successful is a large investment, and the cost of breeding a young dairy stock from birth to first calving age can vary between RM4,710 (USD 1,124) to RM9,048 (USD 2,159) (Gabler et al. 2000; Heinrichs et al. 2013; Hawkins et al. 2020). (Currency convert 12th July 2021). Rearing dairy young stock represents $15-20 \%$ of the total cost of milk production (Hutchison et al. 2017). Do et al. (2013) stated that reducing the age at first, calving from 32.8 months to 22.3 months (10 months), enable farmer earns an extra profit of RM6,779 (USD1,636) (currency convert 22nd June 2021). It is crucial to understand and control the cost of rearing young dairy stock to remain competitive in the industry (Dhuyvetter, 2020). To our knowledge, there are only a few studies about young stock rearing in Malaysia. The current research is important to increase the awareness of important stakeholders in the dairy industry of the growth, management practices, and cost of rearing and to ensure the dairy industry's sustainability.

The study's objectives are (1) to determine the management practices and the costs of rearing, and (2) to analyze the growth performance of young dairy stock from birth to first calving age based on Friesian blood level in Malaysia. This study hypothesizes that different farm management practices in commercial farms determine the overall rearing cost. The results from this study will elucidate the total rearing cost of young dairy stock from birth to first calving age under different farm management and provide further insights into the profitability and sustainability of the dairy farms in Malaysia.

\section{METHODS}

Two dairy farms were selected by convenient sampling based on the availability of bodyweight data where each of the dairy farms is in Keningau, Sabah (5.3289 $\left.{ }^{\circ} \mathrm{N}, 116.1826^{\circ} \mathrm{E}\right)$ and Ayer Hitam, Johor $\left(1.9941^{\circ} \mathrm{N}\right.$, $\left.103.2207^{\circ} \mathrm{E}\right)$. These are intensive system, commercial and Malaysian Good Agricultural Practice (MyGAP) certified farms with Friesian crossbreed. The land size of the dairy farm in Johor is 600 acres and 277 acres in Sabah. Data of total milk production and herd size (2017-2019) were retrieved from the Dairy Farmers' Association (PPTS), Dairy Industry Service Centre, Sabah (PPIT), and Ayer Hitam Livestock Breeding Centre (PTH) (Figure 1). The herd size of the dairy farm was 214 heads and 2,221 heads, and total milk 
production was 163,682 liters and 4.2 mils liters in Johor and Sabah, respectively. The data were edited and analyzed descriptively.

A survey was conducted where a questionnaire was tabled. The questionnaire developed in the Malay language was consisted of 6 open-ended, ten closedended, and one semi-open question and categorized into two sections; Section A: management and prices during the dairy young stock rearing (feed, housing, labor, reproduction and disease control, and prevention) and Section B: The background of the farm manager (gender, level of education and years of experience). The questionnaire is available by request to the corresponding author. The survey data was edited and was used to calculate the cost for each type of feed at different rearing periods: i) birth to weaning age (i.e., raw milk and calf milk replacer); ii) weaning to conception age (i.e., dairy cattle pellet and own total mixed ration) and iii) conception to first calving (i.e., dairy cattle pellet and own total mixed ration) in each farm using equation (1) adapted from Ang et al. (2021):

$\Sigma$ Cost of rearing $=[(($ Price $(1,2,3 . . n) \times \operatorname{Amt}(1,2,3 . . n)) \times$ Freq $) \times($ Periodi) $]$ (Eq.1)

Where: Price1,2,3..n (Market price per kg or litre of feed (Different feed type 1,2,3..n) (RM)); Amt1,2,3..n (Amount given for feed type 1,2,3..n ( $\mathrm{kg}$ or litre)); Freq (Number of feeding frequency per day (times)); Periodi (Number of days during rearing period i).

Feed prices used included raw milk (RM2.90/liter), calf milk replacer (CMR) (RM 336/25kg), dairy cattle pellet (RM81.20/50kg), and total mixed ration (TMR) (RM61.50/50kg). Only feeding costs were considered in our study (USD1=MYR4.12 currency convert 6th June 2021) as it represents the highest costs in young stock rearing (Boulton et al. 2017).

The individual animal data and body weight data were collected from 73 animals in Johor and 150 animals from Sabah and contained variables such as identification number, dam identification number, birth date, date of weighing, and the Friesian blood levels percentage for crossbreed dairy young stock (Equation 2) categorized into i) Group $A=60 \%$ Friesian blood levels ( $\mathrm{n}=26 ; 360$ observations); ii) Group $\mathrm{B}=70 \%$ Friesian blood levels ( $\mathrm{n}=12,164$ observations) and iii)
Group C $=87.5 \%$ Friesian blood levels ( $\mathrm{n}=150,1,022$ observations). Data was edited by, firstly removing data of 1 female calf ( $40 \%$ Friesian blood level) and 34 male calves where there are 26 male calves with $60 \%$ Friesian blood levels and eight male calves with $70 \%$ Friesian blood levels.

Blood level of calf $(\%)=$ Friesian blood of sire $(\%)+$ Friesian blood of dam (\%) (Eq.2)

Where: Blood level of calf (\%) (blood level of calf); Friesian blood of sire (\%) (Friesian blood of sire); Friesian blood of dam (\%) (Friesian blood of dam).

Secondly, the bodyweight data were sorted according to the age (days) calculated in equation (3). Thirdly, the bodyweight at different age groups $(0,3,6$, and 12 months) was analyzed descriptively. Fourthly, as mature bodyweight data was unavailable, third-degree (cubic) polynomial regression analysis was derived using data analysis add-in software to form the following mathematical expression (Eq.4-Eq.6) for each Friesian blood level category to predict the daily body weight. The predicted bodyweight was fitted into a polynomial regression equation to plot the growth curve. Finally, the coefficient of determination $\left(\mathrm{R}^{2}\right)$ was determined to ensure the goodness of fit of the regression model. Data was collected, edited, and analyzed in the Microsoft Excel (Microsoft Corp. Redmond, WA, USA) and IBM Statistical Package for Social Sciences (SPSS) version 25.0.

Age $($ day $)=$ Measured Date - Birth Date (Eq.3)

$\mathrm{Y}_{60 \%}=21.603+0.2697 \mathrm{x}+0.0004 \mathrm{x}^{2}+\left(-4 \mathrm{E}-07 \mathrm{x}^{3}\right)$ (Eq.4)

Where: $\mathrm{Y}_{60 \%}$ (Predicted bodyweight for $60 \%$ Friesian blood level (kg)); $Y_{0}(21.603 \mathrm{~kg})$ (Average birth weight for $60 \%$ Friesian blood level young stock); $\mathrm{x}$ (Age (day).

$\mathrm{Y}_{70 \%}=22.579+0.3045 \mathrm{x}+0.0002 \mathrm{x}^{2}+\left(-3 \mathrm{E}-08 \mathrm{x}^{3}\right)$

(Eq.5)

Where: $\mathrm{Y}^{70 \%}$ (Predicted bodyweight for $70 \%$ Friesian blood level (kg)); $\mathrm{Y}_{0}(22.579 \mathrm{~kg}$ ) (Average birth weight for $70 \%$ Friesian blood level young stock ); x (Age (day)) 
$\mathrm{Y}_{87.5 \%}=26.427+0.5522 \mathrm{x}+0.0017 \mathrm{x}^{2}+\left(-2 \mathrm{E}-06 \mathrm{x}^{3}\right)$

(Eq.6)

Where: $\mathrm{Y}_{87.5 \%}$ (Predicted bodyweight for $87.5 \%$ Friesian blood level (kg)); $\mathrm{Y}_{0}(26.427)$ (Average birth weight for $87.5 \%$ Friesian blood level young stock ); x (Age (day))

\section{RESULTS}

In Malaysia, until 2019, there are 9 MyGAP certified dairy farms (DVS, 2019). MyGAP is known as public GAP designed based on Global GAP (Hoang \& Hung, 2018) as a guide in adopting sustainable agriculture, which considers the importance of the economy, environment, and society in producing high-quality, safe-to-eat food in Malaysia (Mohd Ali et al. 2020). The two participating commercial farms $(2 / 47=4.25 \%)$ out of 47 commercial dairy farms (unpublished) in
Malaysia can be characterized as MyGAP certified, practicing proper record keeping, and availability of bodyweight data. These are the important inclusion criteria for our study. Moreover, we exclude small-scale and semi-commercial farms as these types of farms do not keep a proper record and tend to rely on manually written record books (Jeyabalan, 2010).

Figure 2 shows the trend of herd size and milk production in studied farms from 2017-2019. The herd size of farms in Sabah decreased by 394 heads while the milk production increased from 2,950,584 to 4,236,237 liters. That means the cows were productive (Moran $\&$ Brouwer, 2013b), and the farms were managed efficiently (Krpalkova et al. 2016). Milk production in Johor showed a fluctuating trend that increased from 152,634 to 179,192 litters (2017- 2018) and slightly decreased to 163, 682 litters in the year 2019, parallel with the herd size. Overall, these two farms showed efficient use of available support services (Uddin et al. 2011).

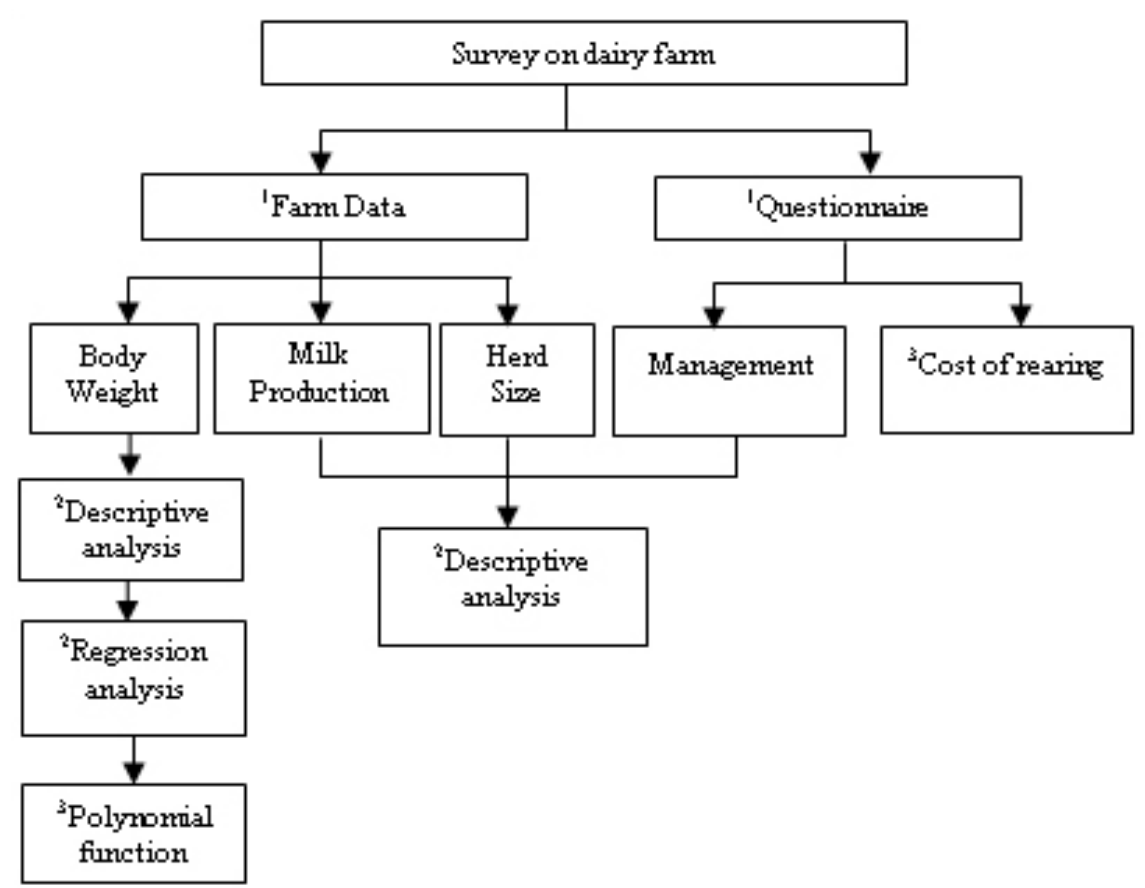

${ }^{1}$ Structured questionnaire used during survey and farm data (herd size, milk production, and body weight measurement) was retrieved from the farm.

2 Data (1 female calf and 34 male calves) were excluded from the data set and the remaining data was sort according to the genetic (Eq. 2), age (day) (Eq. 3) and analyzed using regression analysis. Response from the survey (management) and farm data were analyzed descriptively.

3 The polynomial function was generated using regression analysis (Eq. 4-Eq. 6). The cost of rearing dairy young stock was estimated using Eq. 1.

Figure 1. Research framework of the study. The analysis was based on primary data (survey) and secondary data (farm size and herd size of the farm and bodyweight of individual young stock). 


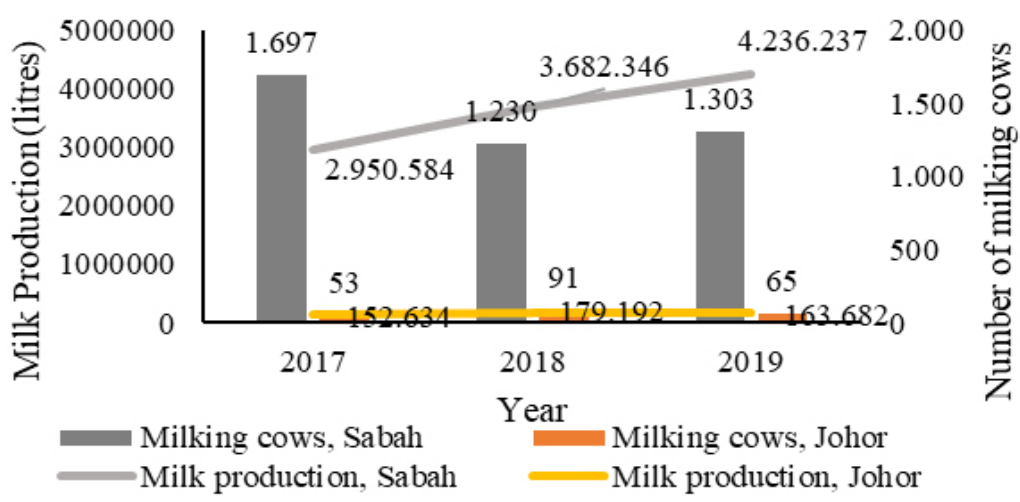

Figure 2. Description of the commercial farms from 2017-2019

The analysis showed the average weight of the young dairy stock with $60 \%, 70 \%$, and $87.5 \%$ Friesian blood levels at birth were $21.31 \pm 3.70 \mathrm{~kg}, 22.33 \pm 2.23 \mathrm{~kg}$, and $26.55 \pm 2.68 \mathrm{~kg}$, respectively; while at three months of age, the average body weight was $45.00 \pm 7.07 \mathrm{~kg}$, $55.57 \pm 8.36 \mathrm{~kg}$ and $75.84 \pm 12.54 \mathrm{~kg}$, respectively. The current study revealed that female heifer took 21 months (630 days) to reach breeding weight $(250 \mathrm{~kg})$ for $60 \%$ and $70 \%$ Friesian blood levels. In contrast, the breeding age for $87.5 \%$ of Friesian blood levels was at 15 months $(444.32 \mathrm{~kg})$. The findings of growth performance according to blood level were similar to the previous study conducted in Malaysia (Mastura et al. 2019) but higher than the study conducted in India (Singh et al. 2015). Mastura et al. (2019) reported the body weight was significantly different between $80 \%$ Friesian blood level with $60 \%$ and $70 \%$. Their study showed a lower performance of $80 \%$ Friesian blood level than our findings, showing different farm management, genetic, and environment of the dairy farm indirectly caused delaying first calving age and slower growth performance that incur a higher cost of rearing (Roessler et al. 2019). However, the growth performance of Friesian crossbreed (60\% and 70\%) in tropics were lower as compared to purebred in the temperate country where this discrepancy was due to management of genetics (Hernández-Castellano et al. 2019), or due to hot and high humidity (Moran \& Brouwer, 2013a), neglect of heifer nutrition and feeding management (Akins, 2016). Dairy farmers were suggested to monitor the realistic body weight as it could affect the long-term milk production, reproductive performance and cause higher rearing costs on the farm (Souissi \& Bouraoui, 2019) if the young dairy stock failed to achieve the realistic target live weights.
The polynomial function according to the different blood levels of Friesian dairy young stock $(60 \%$, $70 \%$, and $87.5 \%$ ) was generated as shown in Figure 3A. Measures of goodness of fit of the polynomial regression function for each blood level of Friesian were $\mathrm{R}^{2}=0.8858(60 \%), \mathrm{R}^{2}=0.9005(70 \%)$ and $\mathrm{R}^{2}$ $=0.9886(87.5 \%)$. The polynomial growth function high coefficient of determination $\left(\mathrm{R}^{2}\right)$ used in this study was able to predict individual growth patterns. It can be incorporated as a decision-support tool to help dairy farmers predict the young dairy stock's body weight and growth performance with the condition of having complete bodyweight measurement data. The polynomial regression function has also been used in previous research in sheep and dairy cattle. Previous researchers concluded that the order of four (cubic) provides a better fit and better reflects the reality of the changes (Sarmento et al. 2011). It does not overestimate body weight measurement compare to the non-linear model (Vijayakumar et al. 2020). However, there is a limitation of polynomial function where the growth curve cannot be extrapolated, as shown in Figure $3 \mathrm{~B}$. The generalizability of these results is subject to certain limitations - for instance, lack of body weight measurement of young dairy stock until first calving age. Dairy farms in Malaysia were suggested to integrate with more advanced technologies to develop more comprehensive tools (e.g., AI vision system) for estimating animal weight. A future study should be repeated by applying other growth functions (e.g., non-linear models) that might help in forecasting body weight measurement.

The estimated costs of rearing young dairy stock at different rearing periods on farms in Johor and Sabah are presented in Table 1. Our study showed that the average cost of raising young dairy stock, which only included the cost of milk and concentrate, was RM3,478 
(USD858)/heifer on dairy farms. Before weaning, dairy calf on farms in Johor was fed raw milk while farms in Sabah were fed calf milk replacer. This study showed birth to weaning as the most expensive rearing period in both farms (Keningau, Sabah and Ayer Hitam, Johor) as RM9.65/day and RM11.60/day, respectively compared to the post-weaning period. The result of this study was in agreement with the previous study conducted in the United Kingdom (Boulton et al. 2015) and Malaysia (Ang et al. 2021). In order to stimulate early weaning, dairy farmers need to focus on rumen development based on solid feed intake and weight at weaning (Sherwin \& Remnant, 2018) to control the pre-weaning period costs.

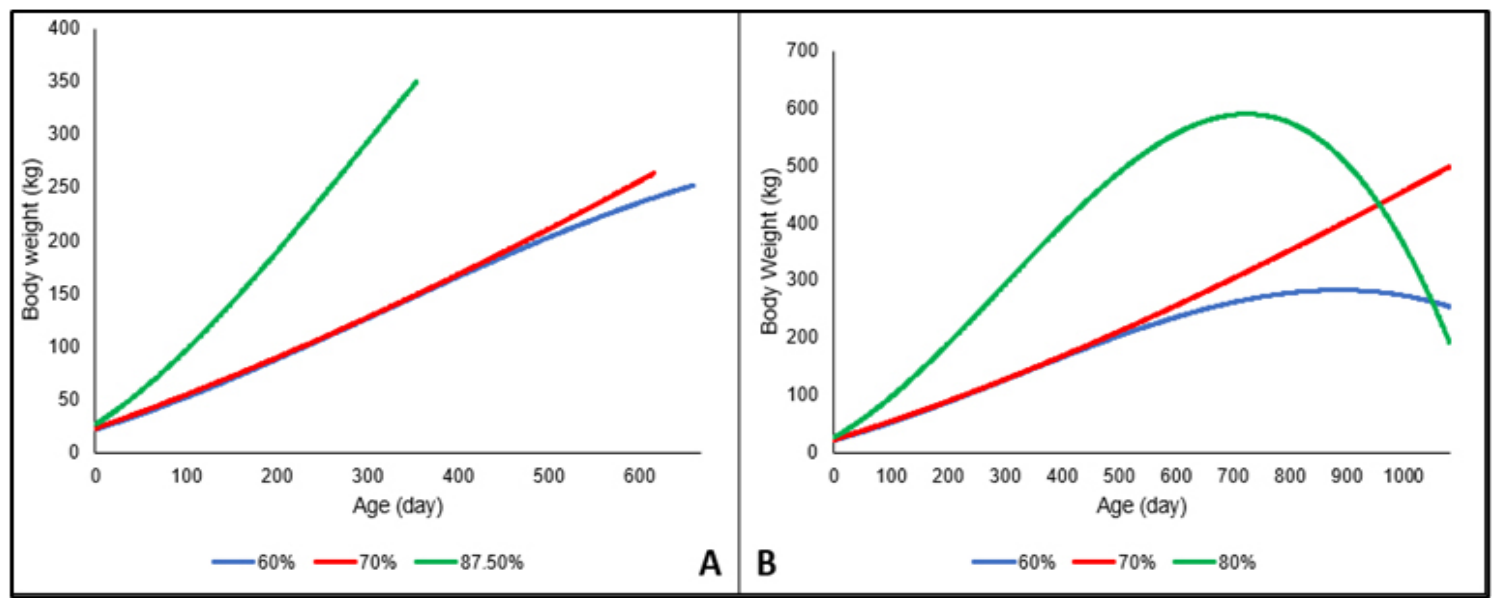

A: The Polynomial growth curve before the body weight of dairy young stock being extrapolate based on the age (day).

B: The Polynomial growth curve was in decreasing trend when the body weight of dairy young stock was extrapolated based on the age (day) thus the body weight only can predict from birth to the age of breeding.

Figure 3. The Polynomial growth curve of crossbreed dairy young stock

Table 1. The average age, body weight, amount of feed and estimated feed cost for rearing young dairy stock in Malaysia.

\begin{tabular}{|c|c|c|c|c|}
\hline \multirow{3}{*}{$\begin{array}{l}\text { Farm location } \\
\text { Blood level of Friesian (\%) }\end{array}$} & \multicolumn{2}{|c|}{ Air Hitam, Johor } & \multicolumn{2}{|c|}{ Keningau, Sabah } \\
\hline & \multicolumn{2}{|c|}{60 and 70} & \multicolumn{2}{|c|}{87.5} \\
\hline & Average age (month) & $\begin{array}{c}\text { Average body } \\
\text { weight }(\mathrm{kg})\end{array}$ & $\begin{array}{c}\text { Average age } \\
\text { (month) }\end{array}$ & $\begin{array}{c}\text { Average body } \\
\text { weight }(\mathrm{kg})\end{array}$ \\
\hline Weaning & 3 & 50.28 & 3 & 75.84 \\
\hline Start breeding & 21 & 250.00 & 15 & 444.32 \\
\hline \multirow[t]{2}{*}{${ }^{1}$ First calving } & 30 & - & 24 & - \\
\hline & Cost (RM) & $\begin{array}{c}\text { Amount of feed } \\
(1 / \mathrm{kg})\end{array}$ & Cost (RM) & $\begin{array}{c}\text { Amount of feed } \\
(1 / \mathrm{kg})\end{array}$ \\
\hline Birth to Weaning & $1,044.00$ & ${ }^{2} 360$ & 868.50 & ${ }^{3} 450$ \\
\hline Weaning to Breeding & $2,770.20$ & ${ }^{4} 1,710$ & $1,771.20$ & ${ }^{5} 1,440$ \\
\hline Breeding to first calving & $1,749.60$ & ${ }^{4} 1,080$ & $1,660.50$ & ${ }^{5} 1,350$ \\
\hline Total & $65,563.80$ & - & $74,300.20$ & - \\
\hline
\end{tabular}

${ }^{1}$ The body weight data is only available from birth to breeding; ${ }^{2}$ Amount of raw milk (liters) in 90 days of the pre-weaning period; ${ }^{3}$ Amount of calf milk replacer (liters) in 90 days of pre-weaning period; ${ }^{4}$ Amount of dairy cattle pellet (kg) provided; ${ }^{5}$ Amount of total mixed ration (kg) provided; ${ }^{6}$ The rearing costs only include feed costs (raw milk and dairy cattle pellet); ${ }^{7}$ The rearing costs only include feed costs (calf milk replacer and total mixed ration). 
After weaning, the dairy heifer was fed dairy cattle pellet (DCP) in Johor while heifers in Sabah were fed total mixed ration (TMR). The amount of feed provided from birth to the first calving age is shown in Table 1. The total cost of the rear (only feed costs) in this study was higher than $€ 849$ (USD696) per heifer reported in the Jonkos research from The Netherlands but similar to the United States, which estimated USD855 per heifer (Hawkins et al. 2020). Feed cost represents the largest contribution to the total cost of rearing (Boulton et al. 2017). The feed cost depends on the feed price (Haryo et al. 2017), type of feed, and amount of feed given (Karadas \& Birinci, 2019). In addition, the delay of first calving age (FCA) showed a higher cost of rearing as compared to the suggested FCA (24-25 months) (López-Paredes et al. 2018). The study is limited by the lack of information on labor, healthcare, and mortality costs due to incomplete data. Notwithstanding these limitations, the study suggests that the dairy farmer in Malaysia should choose the alternative type of feed that is cost-effective and targeted earlier, first calving age, to improve the sustainability of the dairy farms.

This study elucidates the management practices, total cost of rearing, and growth performance of young dairy stock from birth to first calving age. The current findings fill the knowledge gap from previous works that focused on the rearing methods of dairy calves (Devendra \& Eitaro, 1984), feeding management and cost of feed nutrients (Moran \& Brouwer, 2013a), and the growth performance of Mafriwal cattle in Malaysia (Mastura et al. 2019). In practice, the young dairy stock is raised as a replacement herd for culled dairy cows, which is critical to the future of dairy farms because it maintains herd sizes and the performance of the enterprise (De Vries, 2017). Therefore, the knowledge of costs associated with dairy young stock rearing results will reduce the average first calving age and increase the enterprise's profitability. This study, therefore, offers valuable insights on the management and costs associated with young stock rearing in tropical dairy farming in Malaysia. These findings further highlight the important elements in rearing young dairy stock, which increase the awareness of different stakeholders (government agencies, dairy farmers, researchers) on how much to invest in young stock rearing to ensure the farm's sustainability in line with the National Agro-food Policy 2011-2020 and Dairy Plan 20212025 so that they do not blindly invest. For instance, the Polynomial function that used the actual Malaysian farm data to predict the dairy young stock's body weight can be used by farmers to estimate feed and ensure young stock development is on track. The daily cost of rearing Friesian crossbreed dairy young stock in Malaysia in Figure 4.

\section{Managerial Implications}

The results of this study will help dairy farmers, researchers, and government agencies to better understand how much to invest in young stock rearing to maintain farm sustainability in line with the National Agro-food Policy 2011-2020 and Dairy Plan 2021-2025. Dairy farmers can use the predicted body weights using the Polynomial function based on data from Malaysian farms to predict the bodyweight of dairy young stock to estimate feed costs and ensure the expenses of young stock rearing.

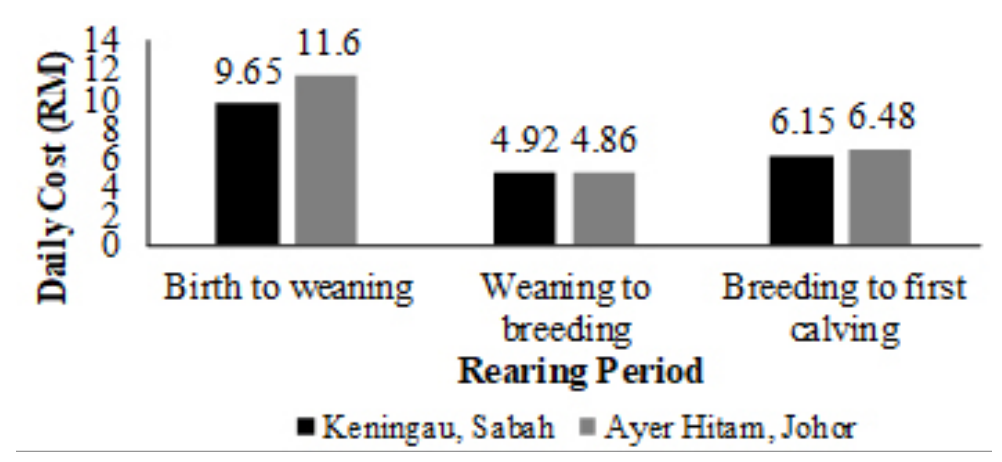

Figure 4. The daily cost of rearing Friesian crossbreed dairy young stock in Malaysia. 


\section{CONCLUSIONS AND RECOMMENDATIONS}

\section{Conclusions}

Our study reported that the average total cost of rearing (first calving age) on dairy farms in Johor and Sabah are RM5,563 (30 months) and RM4,300 (24 months), respectively. The results also showed the two farms have youngstock with different Friesian blood levels (60\% and $70 \%$ in Johor and $87.5 \%$ in Sabah) have different growth performances. In conclusion, growth performance and costs of rearing young dairy stock were varied due to different farm management, genetic, and environment of the dairy farm.

\section{Recommendations}

More comprehensive research is needed by including the missing findings (e.g., cost of mortality, cost of breeding) to increase the accuracy and applied function that can forecast (e.g., non-linear models) the growth performance of a young dairy stock that may help in economic evaluation.

\section{ACKNOWLEDGMENTS}

The authors would like to acknowledge DVS Sabah and PTH Ayer Hitam for their support and Malaysian Research University Networks (MRUN) for the funding of Project 324927 (MRUN/2020/5539500) Title: Precision veterinary surveillance system to support dairy young stock rearing decisions.

\section{REFERENCES}

Akins MS. 2016. Dairy heifer development and nutrition management. Veterinary Clinics of North America - Food Animal Practice 32(2):303-317. https://doi.org/10.1016/j.cvfa.2016.01.004

Ang XT, Nor NM, Hiew MWH, Khairuddin U, Tan CT, Suhaimi NAM, Lee PAK. 2021. Estimating dairy young stock rearing cost of different management systems in Keningau, Sabah, Malaysia. Asian Journal of Dairy and Foods Research 1:1-6. https://doi.org/10.18805/ajdfr. DR-217.Submitted

Boulton AC, Rushton J, Wathes DC. 2015. A Study of Dairy Heifer Rearing Practices from Birth to Weaning and Their Associated Costs on
UK Dairy Farms. Open Journal of Animal Sciences 5(2):185-197. https://doi.org/10.4236/ ojas.2015.52021

Boulton AC, Rushton J, Wathes DC. 2017. An empirical analysis of the cost of rearing dairy heifers from birth to first calving and the time taken to repay these costs. Animal 11(8):1372-1380. https:// doi.org/10.1017/S1751731117000064

Costa A, Boselli C, De Marchi M. 2021. Effect of body weight and growth in early life on the reproductive performances of holstein heifers. Agriculture (Switzerland) 11(2):1-9. https://doi. org/10.3390/agriculture11020159

Davis TC, White RR. 2020. Breeding animals to feed people: The many roles of animal reproduction in ensuring global food security. Theriogenology 150:27-33.https://doi.org/10.1016/j. theriogenology.2020.01.041

De Vries A. 2017. Economic trade-offs between genetic improvement and longevity in dairy cattle. Journal of Dairy Science 100(5):4184-4192. https://doi.org/10.3168/jds.2016-11847

Department of Veterinary Services. 201). Senarai keseluruhan ladang ternakan MYGAP.

Department of Veterinary Services. 2020. Jabatan perkhidmatan veterinar perangkaan ternakan 2018/2019. http://www.dvs.gov.my/index.php/ pages $/$ view $/ 2758 ? \mathrm{mid}=42 \% 0 \mathrm{Ahttp}: / \mathrm{www} . \mathrm{dvs}$. gov.my/index.php/pages/view/2234? $\mathrm{mid}=42$

Devendra C, Eitaro I. 1984. Improvement of raising method of dairy calves in Malaysia energy sources for calf starter rations. National Istitute of Animal Industry 148-157.

Dhuyvetter KC. 2020. Dairy replacement heifer economics. AABP ANNUAL CONFERENCE PROCEEDINGS 53(2):200-204.

Do C, Wasana N, Cho K, Choi Y, Choi T, Park B, Lee D. 2013. The effect of age at first calving and calving interval on productive life and lifetime profit in Korean holsteins. Asian-Australasian Journal of Animal Sciences 26(11):1511-1517. https://doi.org/10.5713/ajas.2013.13105

Faghiri H, Yusop Z, Eric Krauss S, Hj Othman M, Mohamed Z. 2019. Demonstrating the factors influencing the dairy industry development and milk production level in Malaysia: A hybrid approach of inductive and deductive coding and theme development. International Journal of Modern Trends in Business Research (IJMTBR) 2(10):34-51.

Gabler MT, Tozer PR, Heinrichs AJ. 2000. Development 
of a cost analysis spreadsheet for calculating the costs to raise a replacement dairy heifer. Journal of Dairy Science 83(5):1104-1109. https://doi. org/10.3168/jds.S0022-0302(00)74975-7

Haryo M, Rifin A, Sanim B. 2017. Factors affecting profitability on animal feed companies in Indonesia. Agro Ekonomi 28(2): 289-308. https://doi.org/10.22146/jae.26034

Hawkins A, Burdine KH, Amaral-Phillips DM, Costa JHC. 2020. Effects of housing system on dairy heifer replacement cost from birth to calving: evaluating costs of confinement, dry-lot, and pasture-based systems and their impact on total rearing investment. Frontiers in Veterinary Science 7(October):1-9. https://doi.org/10.3389/ fvets. 2020.00625

Heinrichs AJ, Jones CM, Gray SM, Heinrichs PA, Cornelisse SA, Goodling RC. 2013. Identifying efficient dairy heifer producers using production costs and data envelopment analysis. Journal of Dairy Science 96(11):7355-7362. https://doi. org/10.3168/jds.2012-6488

Hernández-Castellano LE, Nally JE, Lindahl J, Wanapat M, Alhidary IA, Fangueiro D, Grace D, Ratto M, Bambou JC, de Almeida AM. 2019. Dairy science and health in the tropics: Challenges and opportunities for the next decades. Tropical Animal Health and Production 51(5):1009-1017. https://doi.org/10.1007/s11250-019-01866-6

Hoang, Hung. 2018. Farmers' Responses to VietGAP : A Case Study of a Policy Mechanism for Transforming the Traditional Agri-food System in Vietnam. New Zealand: Massey University.

Hutchison JL, VanRaden PM, Null DJ, Cole JB, Bickhart DM. 2017. Genomic evaluation of age at first calving. Journal of Dairy Science 100(8):6853-6861. https://doi.org/10.3168/ jds.2016-12060

Jeyabalan V.2010. Individual cow recording and analysis system for small scale dairy farmers in Malaysia. International Journal of Computer Applications 8(11):33-38. https://doi.org/10.5120/1247-1621

Karadas K, Birinci A. 2019. Determination of factors affecting dairy cattle: A case study of ardahan province using data mining algorithms. Revista Brasileira de Zootecnia 48:1-11. https://doi. org/10.1590/RBZ4820170263

Krpalkova L, Cabrera VE, Kvapilik J, Burdych J. 2016. Dairy farm profit according to the herd size, milk yield, and number of cows per worker. Agricultural Economics
(Czech Republic) 62(5):225-234. https://doi. org/10.17221/126/2015-AGRICECON

López-Paredes J, Angeles Pérez-Cabal M, JiménezMontero JA, Alenda R. 2018. Influence of age at first calving in a continuous calving season on productive, functional, andeconomic performance in a Blonde d'Aquitaine beef population. Journal of Animal Science 96(10):4015-4027. https:// doi.org/10.1093/jas/sky271

Lukuyu MN, Gibson JP, Savage DB, Duncan AJ, Mujibi FDN, Okeyo AM. 2016. Use of body linear measurements to estimate liveweight of crossbred dairy cattle in smallholder farms in Kenya. SpringerPlus 5(1):1-14. https://doi. org/10.1186/s40064-016-1698-3

Mastura Y, Shariffah NY, Nor Aini W, Muhammad Ali Hanapiah AM, Mohd Hafiz AR, Chandrawathani P. 2019. Malaysian journal of veterinary research growth performance of mafriwal dairy cattle in. Malaysian Journal of Veterinary Research 10(1):43-50.

Mohd Ali NI, Ibrahim NI, Aiyub K, Kasavan S. 2020. Pelaksanaan amalan pertanian baik (GAP) dalam kalangan pesawah padi di Sekinchan, Sabak Bernam, Selangor. Malaysian Journal of Society and Space 16(3):247-262. https://doi. org/10.17576/geo-2020-1603-18

Moran JB,Brouwer JW.2013a.Feedingmanagementand farmer concerns about constraints to production on Malaysian dairy farms. International Journal of Agriculture and Biosciences 2(5):221-233. www.ijagbio.com

Moran JB, Brouwer JW. 2013b. Interrelationships between measures of cow and herd performance and farm profitabilty. International Journal of Agriculture and Biosciences 2(5):221-233.

RahbarR,AbdullahpourR, Sadeghi-SefidmazgiA.2016. Effect of calf birth weight on milk production of holstein dairy cattle in desert climate. Journal of Animal Behaviour and Biometeorology 4(3):6570. https://doi.org/10.14269/2318-1265/jabb. v4n3p65-70

Sarmento JLR, Torres, R. de A, Sousa WH, de Albuquerque LG, de Lôbo RNB, Sousa JER de. 2011. Modeling of average growth curve in Santa Ines sheep using random regression models. Revista Brasileira de Zootecnia 40(2):314-322. https://doi.org/10.1590/s151635982011000200012

Singh VP, Dubey, M, Pandey RK. 2015. Effect of different feed combinations on the growth 
performance of cross-bred heifer calves. Asian Journal of Animal Sciences 9(5):225-232. https://doi.org/10.3923/ajas.2015.225.232

Souissi W, Bouraoui R. 2019. Relationship between body condition score, milk yield, reproduction, and biochemical parameters in dairy cows. In Intechopen. https://www.intechopen.com/books/ advanced-biometric-technologies/livenessdetection-in-biometrics

Tebug SF, Missohou A, Sabi SS, Juga J, Poole EJ, Tapio M, Marshall K. 2018. Using body measurements to estimate live weight of dairy cattle in lowinput systems in Senegal. Journal of Applied Animal Research 46(1):87-93. https://doi.org/1 0.1080/09712119.2016.1262265

Uddin MM, Sultana MN, Ndambi OA, Alqaisi O, Hemme T, Peters KJ. 2011. Milk production trends and dairy development in Bangladesh. Outlook on Agriculture 40(3):263-271. https:// doi.org/10.5367/oa.2011.0056
Uzir MM. 2019. Selected Agricultural Indicators, Malaysia, 2019. Department of Statistics Malaysia. https://www.dosm.gov.my/v1/index. php $\mathrm{r}=$ column/cthemeByCat\&cat $=405 \&$ bul_id $=$ bEkvWDRrSWw4OGttVTduamVmWVN5U T09\&menu_id=Z0VTZGU1UHBUT1VJMFlpa XRRR0xpdz09

Van Eetvelde M, Opsomer G. 2017. Innovative look at dairy heifer rearing: Effect of prenatal and post-natal environment on later performance. Reproduction in Domestic Animals 52:30-36. https://doi.org/10.1111/rda.13019

Vijayakumar M, Choy Y-H, Kim T-I, Lim D-H, Park S-M, Alam M, Choi H-C, Ki K-S, Lee H-J. 2020. Models describing growth characteristics of holstein dairy cows raised in Korea. Journal of The Korean Society of Grassland and Forage Science 40(3):167-176. https://doi.org/10.5333/ kgfs.2020.40.3.167 